\title{
FORMER STUDENTS OF THE RIGA POLYTECHNICUM AND RIGA POLYTECHNIC INSTITUTE (1862-1919) - LITERARY WORKERS
}

\section{ALĪDA ZIGMUNDE* \\ Riga Technical University \\ ERIKA LANKA, ELITA STIKUTE \\ University of Latvia \\ ZANDA ŠLEGELMILHA}

Kuldiga Technology and Tourism Technical School

Summary. The authors of the article have gathered literary works of poets and writers - former students of Riga Polytechnicum (RP) and Riga Polytechnic institute (RPI), and have characterized them. Several Latvian and foreign literary workers have studied at the institute. Only six of them - Alfrēds Andersons, Jānis Bergs, Rihards Ërglis, Ernests Eferts, Jānis Mikelsons and Arvīds Valdmanis - received diplomas in engineering after graduating from Departments of Engineering, Commerce and Agriculture. A. Valdmanis has written course books and literary works. Latvian poet Jānis Poruks and Russian writer Mihail Prishvin (Muxauл Михаилович Пришвин) have also studied at the institute, but just like few others did not become engineers and are known due to their achievements in literature. RPI graduate admiral Teodors Spāde also wrote poems.

Keywords: Riga Polytechnicum, Riga Polytechnic Institute, writers with engineering education.

\section{Introduction}

Life in Europe, in the 19th century was interesting and multifaceted under social and historical, philosophical, cultural and economic aspects. The enormous colonial systems of the great powers of Europe were

\footnotetext{
* Corresponding author.

E-mail: alida.zigmunde@rtu.lv
} 
slowly breaking down and people were moving from the usual agrarian environment to urban environment - to megacities. The industrialization flourished and there was an ever-growing demand for workforce, which brought about new nuances in the way of life, and gave impulse to production and science. Engineering was rapidly developing, requiring engineers with higher education who could build and design cities, individual civil engineering structures, and ensured advent of engineering achievements in the life of each person and society.

Changes took place in the territory of present Latvia, including Riga. The Riga Polytechnicum (RP) (Riga Polytechnic School), founded in 1862, and its successor Riga Polytechnic Institute (RPI), reorganized in 1896, was an institution educating engineers, specialists not only for the Baltic provinces. Literary science developed alongside engineering, and the number of published newspapers, magazines and books increased. The level of education was growing. Students were eager readers and used the extensive library of the institute, where works of literary science and mythology could be found alongside engineering literature [1]. Part of the students wrote themselves, and their interest in literature determined their future way of life. Several dozen students were members of editorial boards of magazines and newspapers, but in this article, only those who have created literary works, as well as translated them, or have done literary studies will be mentioned.

While gathering information about the literary workers who have been students of the first technical university education institution in the Baltic provinces, it had been concluded that there are a lot of documents and publications about Latvians, but information about foreign writers and poets has only been partial. Students of the Riga Polytechnicum and Riga Polytechnic Institute in the second half of the 19th century and the beginning of the 20th century were of different nationalities; their graduates were employed in the large Russia as well as in Europe. Unfortunately, there is no complete and detailed information about all graduates, and a larger database of former students of the university can be found only in the issues of «Album Academicum» of 1912 and 1938. The collection of short biographies of students and teaching staff issued in celebration of the 50th anniversary of RPI did not list the written, compiled or translated books by these people, and not always there is evidence of literary activities of these persons. There is no information about many former students [2]. The "Album Academicum» issued in 1938 after the 75th anniversary of RPI in 19361 did not contain information on the activities of many students - non-Latvians after 1912 [3]. The authors of the article did not have the opportunity to explore sources

1 It is the only anniversary which is celebrated taking as the basis the date of the approval of the Statutes of the institute on 16 May 1861, rather than its opening in 1862. 
and documents in Armenian, Georgian, Karaim, Hebrew and some other languages, and to check whether the literary works by the "polythechnicans» of different nationalities had been written in those languages. From the publications in Russian wider known is the Armenian revolutionary and literary critic Stepan Shaumyan (Степан Шаумян; 18781918). The authors of the article have focused only on those personalities who are authors of literary writings (stories, poems, novels, plays, etc.) and who have been recognised by literary historians [4; 5], excluding journalists and translators.

\section{Students from Riga Polytechnicum and Riga Polytechnic Institute - Latvian Literary workers}

Only about $5 \%$ of the students at the Riga Polytechnicum and Riga Polytechnic Institute were of Latvian nationality [6] because there were study fees and students from countryside had to rent apartments or rooms in Riga. It was not easy for the sons of Latvian farmers to get the money necessary for studies, but they were supported by their families and relatives, as well as had the opportunity to work or receive some of the few scholarships. For those who had an interest and talent to write something - either a publication, a poem, a story for the local press - or to publish a novel, there was a chance to earn. One of them was the graduate, novelist and narrator Jānis Mikelsons (1882-1926), who studied in the Department of Commerce of the RPI from 1901 to 1910 and is known under the pseudonym Haralds Eldgasts [7]. He began his literary career already during his studies in the journal «Vêrotājs» («The Observer») (1904) and wrote the novel «Zvaigžnotās naktis: vienas dvēseles stāsts» («Starry Nights: A Story of One Soul») (1905). The novel has gained popularity and is considered to be one of the first mono-novels in Latvian literature, ranking the author among decadents [8]. During his studies, J. Mikelsons translated the work of Paul Eltzbacher (1868-1928), Assistant Professor in Law at the University of Halle, «Lev Tolstoy's Views and Teachings on State, Laws and Property» (1907) [9]. It should be noted that Lev Tolstoy (Лев Толстой; 1828-1910) was a very popular writer among the students of RPI. Student J. Mikelsons wrote the preface to the translation of the trilogy "Kristus un Antikrists» («The Christ and the Antichrist») by a Russian writer and religious philosopher Dmitry Merezhkovsky (Дмитрий Мережковский; 1865-1941) into the Latvian language (1908). It should be noted that D. Merezhkovsky was nominated 10 times for the Nobel Prize. J. Mikelsons has also written the following works: a play «Dēmona paradīzē» («In Demon's Paradise ») (1907); an autobiographical work «Pa okeānu: no Rīgas lìdz Nujorkai un atpakal̦»
Former Students of the Riga Polytechnicum and Riga Polytechnic Institute (1862-1919) Literary Workers 
(«By the Ocean: From Riga to New York and Back») (1912); as well as the novel «Sudrabotā saulē» («In Silver Sun») (1924), which was repeatedly published in 1968. Under the pseudonym Sirotājs (filibuster), J. Mikelsons published feuilletons. RPI graduate J. Mikelsons worked as a teacher in Russia and Latvia, and was an editor of the newspaper «Kurzemes Vārds» («Kurland name») (1923-1926).

Vilis Olavs (until the 1890s - Vilis Plute; 1867-1917), a socially active figure in Latvia and a publicist, who had previously obtained theological education at the University of Tartu, was a graduate of the Department of Commerce of RPI . He is also known for his works on Christianity, and history of Latvia, he has written an important two-volume book entitled «Galvenie virzieni ètikā» («The Main Directions in Ethics») (1910-1918). Vilis Olavs did not write literary works, his friend «polythechnican» Alfrēds Andersons did.

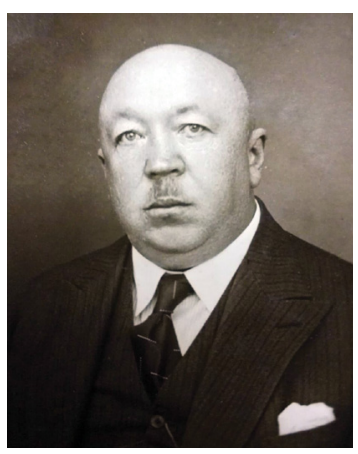

Figure 1. RPI graduate Alfrēds Andersons (around 1930s) [10].

Graduates of RPI Department of Engineering Alfrēds Andersons (18791937) and Rihards Ërglis (1881-1950) have been well-known among their contemporaries, and their contribution to Latvian literature is significant, although neither of them is among the most visible and popular writers and nowadays not everyone knows their names. Alfrēds Andersons worked in literature under the pseudonym Andrass, after graduating from RPI (1904) he had worked as a director and teacher of physics at the V. Olava Trade and Commerce School ${ }^{2}$, during the Republic of Latvia he worked at the Riga Secondary School No. 4, the Riga City Commercial School, as well as was a teacher at the Riga City Technical School and a Director of the Latvian Artist Association Theatre School [11]. For several years, civil engineer A. Andersons was Head of the Riga city (19211928). Alfrēds Andersons wrote poems and short stories, he is the author of dramas «Keeeniñš Dāvids» («King David») (1922) and «Baltezeru dzimtas asins» («The Baltezers Family blood») (1933), staged at the theatre. He

2 Alfrēds Andersons was a friend of RPI graduate Vilis Olavs (1867-1917). 
also translated opera and operetta librettos, such as Richard Wagner's «Tannhäuser» (1919), and «Tristan and Isolde». His contemporary, dramatist Jūlijs Pètersons (1880-1945), wrote: «Our intelligents who graduated from the university are well-versed in their professions, but are less interested in art, literature, and other areas that make life beautiful and complete [12].» However, dramatist J. Pētersons acknowledged that $A$. Andersons was an exception, as he was deeply interested in our cultural and spiritual life already while being at school and as a student, and «with great enthusiasm took up music, literature and art. He could sing by heart the songs by Schubert and Schumann and Wagner's operas. He had an amazing knowledge of our own and foreign literature. He could recite with deep understanding the works of the best poets for hours. He impressed everyone with his knowledge [12].»

Unlike the aforementioned writers, Rihards Ërglis, a graduate of the Department of Engineering (1906) of RPI, was also a historian, he had received a second diploma from the St. Petersburg Institute of Archaeology. He worked as a civil engineer and, after the Second World War, at the Museum of History of Latvia. R. Erglis started literary activities in the 1920s, and his works are based on the sources of history. R. Erglis' historical stories «Sēlli» (1935), «Viesturs» (1936) and «Virsaiša meita» («The Daughter of the Chief») (1939) tell us about the fights of Latvian tribes against the German invaders. He described the scenes of life of the first half of the 19th century and the romantics of working one's own land in his novels «Pelēko baronu vectēvi» («The Grandfathers of Gray Barons») (1928) and «Pelēko baronu tēvi» («The Fathers of Gray Barons») (1929), which were later published in a single book «Pelēko baronu senči» («The Ancestors of Gray Barons») (1937). Engineer and historian R. Ërglis acknowledged history as the main area of his activity, but considered writing as his hobby [13].

Figure 2. Cover of Rihards Ërglis' book (1938) [14].

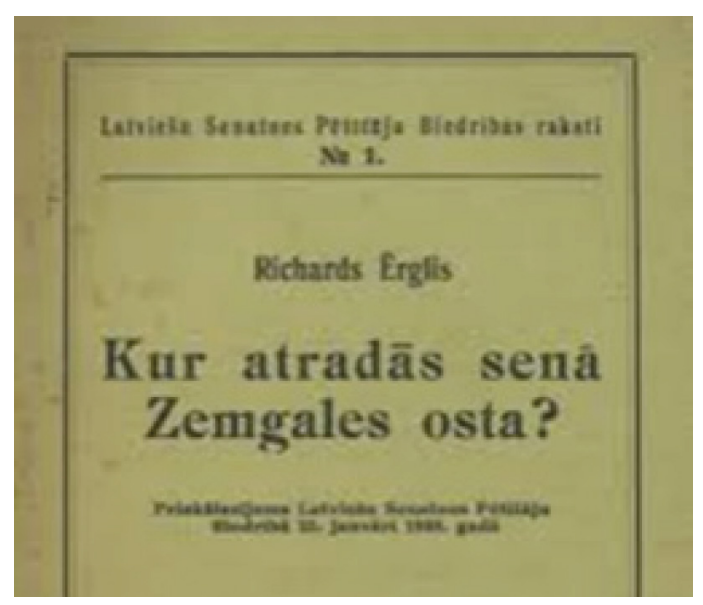

Former Students of the Riga Polytechnicum and Riga Polytechnic Institute (1862-1919) Literary Workers 
The graduate of the Department of Agriculture (1888)š of RP Jānis Bergs (1863-1927) started writing during his study years, writing his own literary works and translating stories, descriptions, articles on agriculture, and pedagogy [15]. While being a student, J. Bergs has written works on his speciality later becoming known as the author of more than 200 articles and books on agriculture [16]. In 1919, he became the first Dean of the Faculty of Agriculture of the newly formed University of Latvia and until 1927 he was a Professor of the University. Along with interest in agriculture, during his school and study years $J$. Bergs was interested in literature and theatre, participated in theatre performances in Jelgava, Liepāja, Bauska and Riga cities. His first literary work, «Česmes varons», was published in the newspaper «Latviešu Avīzes» («Latvian Newspapers») on 21 June 1878, when he was 14 [17]. At the end of his study years (1886-1888) he wrote theatre reviews for «Baltijas Vēstnesis» («Baltic Journal»). J. Bergs was born in Zalenieki. He translated plays and wrote them himself. Some of his plays, such as «Dzimtenē» («In Homeland») (1881), «Mãkslinieks» («Artist») (1883), «Mankus» (1884), «Precības caur precībām» («Marriage Through Marriage») (1886), «Latviešu studentiem par labu» («For the Benefit of Latvian Students») (1887), were staged. They were written and staged, when Jānis Bergs was young and was studying at the Jelgava Real School and at the Riga Polytechnicum [18]. His literary pseudonyms were Kalninš and Jaunjānis.

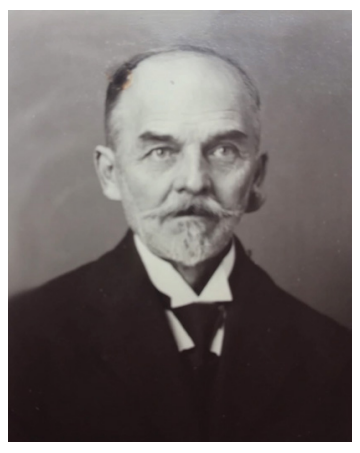

Figure 3. Jānis Bergs (around 1926) [19].

A graduate of the Department of Agriculture of RPI (1914) Ernests Eferts (also Eferts-Klusais; 1889-1927), after receiving an agronomist's diploma was involved in the Communist Party, is known as a party worker and spent his life in the Soviet Union. At the beginning of 1919, he returned to his homeland, was the Deputy Commissar of the Soviet People's Commissariat for Education and Head of the Department of Higher Education, he supported the establishment of the University of Latvia through consolidation of the sciences taught at the polytechnical 
high school and at university in a single institution. He also accepted the transfer of RPI's property to Russia in 1918 [20]. He studied chemistry from the 27 February-22 May 1919 at the University of Latvia, founded and managed by the Soviet authorities [21]. Ernests Eferts is the author of several literary works, and during the Soviet time, his name and books were highly regarded at schools whose students had to study his literary work - a brochure on the Latvian Social Democrat, writer Janis Jansons-Brauns (1882-1917) [22]. Ernests Eferts has published articles and stories on education issues, workers, etc. He translated writings on politics and of popular science. Let us mention some of his books: «Nemiera sirotājs: fragmenti» («Immersion Follower: Excerpts») (1923), «Piezìmes par latviešu ideoloǵijas vēsturi» («Notes on the History of Latvian Ideology») (1925). Almost all Eferts' works have been published in Soviet Russia in 1920-1930, but after the Second World War some of them have been translated into Russian in Latvia. Their ideology corresponds to the spirit of the Soviet era. For example, the story «Pierobežas aprinkis» («Border Region») (1926) suggests that E. Eferts, a resident of Russia, was an opponent of the new independent Latvia and a denier of the Latvian War of Independence, who supported communists [23].

Arvids Valdmanis (1890-1942), the third graduate of the Department of Agriculture (1915) of RPI, under the pseudonym Arvìds Spodris began publishing already during his studies, but later wrote his works as Kuri-Beri. He worked as an agronomist, and from 1934 until the end of his life as a teacher at the Zalenieki School of Home Economics, and later - a Director. Agronomist A. Valdmanis has enriched agricultural study materials with works in the dairy and livestock sector. He wrote such books as «Dzivnnieku anatomija un fizioloǵija» («Anatomy and Physiology of Animals») (1923), which was re-issued with supplements in 1929 and 1947, and «Piensaimniecība» («Dairy Farming») (1929), «Ievads piensaimniecībā» («Introduction to Dairy Farming») (1934), «Lopkopība» («Animal Husbandry») (1936). Arvìds Valdmanis compiled the anthology of humorous and satirical poetry «Jautrās mūzas» («Merry Muses») (1925) and wrote such kind of poems and stories himself. His works have been published in the magazines «Svari» («Weigh») [24], «Mūsu Mājas Viesis» ("Our home guest»), in the newspaper «Sikspārnis» («Bat») and in other magazines. The radioplays written by him, the satirical book «Zvirbuli cilpās» («Sparrows in the Loops») (1922), play «Pēdejjā diena» («The Last Day») (1924), and comedy «Viena vasara» («One summer») (1939) have to be mentioned. A significant resource for him were the negative traits of human nature and public life [25]. Writer and humorist A. Valdmanis has written comedies for Zalenieku amateur theatre and directed them, his work in literature and theatre history is still remembered in Zalenieki parish [26]. 


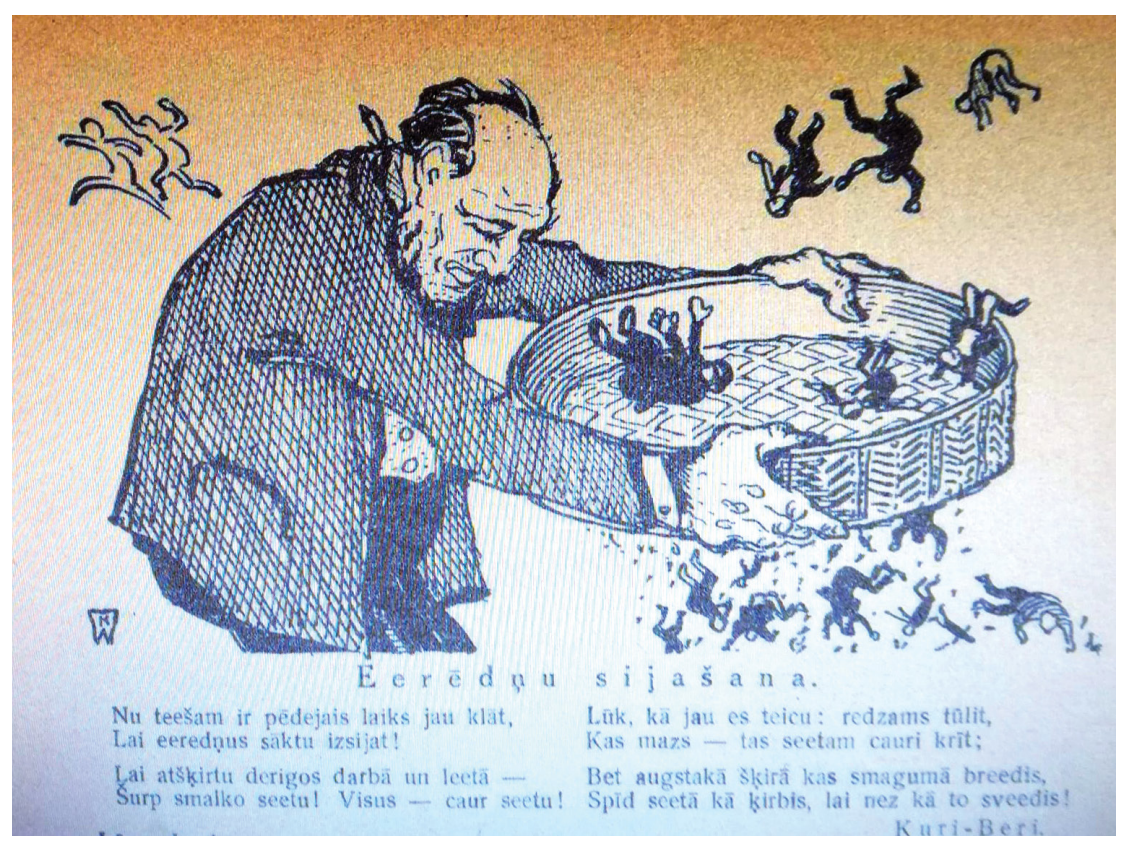

Figure 4. The poem «Ierēdṇu sijāšana» («Sifting of Officials») by Arvīds Valdmanis (Kuri-Beri) in journal «Svari» («Weigh») No. 39, 1921 [24].

Some literary workers did not have university degrees. Among them was the poet and writer Jānis Poruks (1871-1911), who was preparing for the engineering studies at the Preparatory School of Riga Polytechnicum (1889-1892) and studied at the Department of Chemistry (1897-1899) and at the Department of Commerce (1901-1905) of RPI, and was a member of the Latvian Student Corporation «Selonija». The stories by Jānis Poruks «Kauja pie Knipskas» («Battle at Knipska»), «Pērlu zvejnieks» («Pearl Fisherman») and others are widely read, music has been written to his poems. Writer and art theorist Viktors Eglitis noted that Poruks stands out «as the third and perhaps the most eloquent of the Latvian «golden literature representatives» of the 19th century along with Rainis and Fallijs [27].»

Writer and journalist Nikolajs Puriňš or Puriņu Klāvs (1858-1935) also attended the Preparatory School of Riga Polytechnicum and later studied architecture for several years and worked in the office of architect Jānis Frìdrihs Baumanis, but did not receive a diploma. While being a student, he wrote poetry. He stopped his studies and worked in the newspaper «Baltijas Vèstnesis» («Baltic Messenger») (from 1890) becoming an editor (1896-1905), editor of the newspaper «Latviešu Avīzes» («Latvian Newspapers») (1909-1915), and at the end of the 19th century he turned to writing stories such as «Lielkungu pusdienas» («The Lunch of 
Lords») (1889), «Zviedris» («The Sweden») (1890), «Nauda» («Money») (1893). His drama «Zviedris» was the best of his plays and was featured at the National Theatre at the anniversary of the student corporation «Selonija». Klāvs Purinš was one of the founders of this corporation. He was also very interested in history [28], it is evidenced by his work «Latvieši, divdesmitajam gadu simtenim atnākot» («Latvians in the Beginning of the Twentieth Century») (1901), as well as his work on supplementing German-Baltic writer Otto von Ruthenberg's (1802-1854) work «Baltijas vēsture» ${ }^{3}$ («History of the Baltics») (1859-1860) with the latest research (1901). During the first independent Latvia, Klāvs Purin̄š worked as the manager of the Saeima Library.

Writer, educator and journalist Arveds Smilga (1879-1947) also had studied architecture (1899-1901) at RPI [29]. He is known as the director of the Cesvaine Gymnasium (1929-1934) and the Director of Latvijas Radiofons (1934-1940). He had compiled a textbook for learning German, written poetry, translated novels «Luizite» and «Tristans» by German writer, Nobel Prize winner Thomas Mann (1875-1955).

Chemistry at RPI was studied (1913-1916) by writer and journalist, Minister of National Welfare Jülijs Lācis (1892-1941), who is known for the novel about the exodus of Latvians to Brazil «Mūža meža maldi» («Delusion of Eternal Forest») (1936-1937).

Several literature students have studied at the Department of Commerce of RPI. Poet Valdemārs Šènfelds (from 1940 - V. Skaistlauks; 18921972) was enrolled on 1 September 1910, then he voluntarily joined the Czarist Russian Army and on June 1912 he interrupted studies, restarting them only in the academic year 1913/1914 [30]. Then he went to war in both the Russian and later Latvian Army. He was awarded the Order of Läčplēsis for his participation in the Latvian War of Independence. V. Šènfelds' poems are dominated by the patriotic theme.

Writer Karlis Jêkabsons (1979-1946) started to write poems at the age of 13, but joined RPI in 1910, when he was 31 years old, and was studying with several interruptions due to lack of money until the end of 1914 [31]. He wrote ballad «Sniegbaltite» («Snow-white») (1906) and many other works, but most of them are regarded weak by literary critics [32]. Widely known is novel «Heinrihs Rautenfelds» (1929-1930 in six volumes; repeated 1994 in two volumes). The novel is based on a true story of a Baron, who shot his doctor in 1912 in the centre of Riga [33]. Baron Heinrich Berens von Rautenfeld's (1882-1929) brother Hans Berens von Rautenfeld (1883-1912) studied at RPI and committed suicide several months before the fatal shot of his brother. Their brothers Friedrich and Paul studied agriculture at RPI. Perhaps writer K. Jēkabsons and Baron von Rautenfeld studied at the same time, perhaps they even

\footnotetext{
3 The original name of the work is «Geschichte der Ostseeprovinzen Liv-, Esth- und Kurland
} von der aeltesten Zeit bis zum Untergange ihrer Selbstaendigkeit».
Former Students of the Riga Polytechnicum and Riga Polytechnic Institute (1862-1919) Literary Workers 
knew each other personally, and the writer when creating the literary work, was interested in the tragedy of the young Rautenfeld. This event also prompted the creation of movie «Vilkiem mests laupijums» («The Loot Thrown to Wolfs») in the 1920s, but writer Pāvils Gruzna wrote the story «Rautenfelda mīlas traǵédija» («Rautenfeld's Love Tragedy»), which was staged at the Daile Theatre. The tragic event and the destiny of the Rautenfelds are still being discussed.

A revolutionary, writer and journalist Jānis Māsters (1884-1938), who wrote his works under the pseudonym Jānis Straujāns [34], studied for a short time (1903-1904) in the Department of Commerce of RPI. From 1 September to 3 October 1914, the name of the writer, a commander of the Soviet Army Roberts Eidemanis (1895-1937) [35] was on the list of chemistry students.

A graduate of the Department of Mechanical Engineering of RPI (1914) Teodors Spāde (1891-1970) is known as Latvian seaman, Navy officer, Commander of the Latvian Sea Coast Defence Squadron (19311938), commander of Latvian Navy, Admiral (1938-1940). Although we cannot call him a poet, T. Spāde is the author of several poems. For example, his poem «Es esmu latvietis» («I am a Latvian») is very popular. It starts as follows:

«Es esmu latvietis -

Man dzīslās kuršu asins rit, Es esmu latvietis Cik skaisti zināt to ikbrīd [36].»
«I am a Latvian -

Kurlandian blood is running in my veins, I am a Latvian -

How beautiful it is to know it every moment [36].»

Part of T. Spāde's poems have been put to music. For example, R. Jermaks' oratorio «Sāpju celšs» («The Road of Pain») fourth part «Lügšana» («Pray») author of the words is T. Spāde [37]. In 1939, in the service of the 20th anniversary of the Latvian Navy at the Brālu Cemetery the song «No jūras krastiem nākam mēs» («We come from the coasts of the sea») was performed - the author of the poetry is T. Spāde, but the music was later used in the coral «Dievs kungs ir müsu stiprā pils» («God is our Stronghold») [38]. The Admiral's poems were devoted to Latvia and its beauty, about homeland, the Amber Sea, the words of God and many other things and facts that were important to him. 


\section{Writers of other nationalities - students of the Riga Polytechnicum and Riga Polytechnic Institute}

Three German-Baltic writers were thinking of the career of an engineer when they were young, but they did not complete their studies at the university in Riga. Moritz Kerkovius (1860-1881), a son of the Riga city councillor Ludwig Wilhelm Kerkovius (1831-1904), studied in the Department of Commerce (1878-1881) of RP. Unfortunately, he had to interrupt his studies due to kidney disease. In February 1881, he went for a treatment to Germany, France, Algeria, Italy, and then to Cairo, where on November 12, his life ended. His father founded a scholarship at the Riga Polytechnicum dedicated to his son, but his works, published in German under the pseudonym Bruno Mohren, remained in the literature. Moritz Kerkovius' only collection of poems - «Vermischte Gedichte. Baltische Klaenge» («Mixed poems. Baltic sounds.») - was published in Zurich in 1880, but some writings were published in various newspapers and journals [39].

A German-Baltic writer Adolf Julius J. Lyra (1883-?) studied in the Department of Commerce (1902-1905) of RPI, but apparently, because of the revolutionary events he interrupted his studies in Riga and went to Vienna and later to the University of Munich to study national economy and philosophy. His dramas «Es werde Gott» («It will become God») and «Aus Wolke und Wueste» («From the cloud and the desert») were published in Germany in 1908 [40]. The writings of German-Baltic writer Auguste Arthur von Loewis of Menar (1881-1930), who studied agriculture (1903/1904), were published in German in Germany and are not known in Latvia.

Russian writer, author of the book on nature Mihail Prishvin (Михаuл Михаилович Пришвин; 1873-1954) studied chemistry (1893-1897) and agriculture (1897-1898) in Riga [41]. He was busy not only with the studies in chemistry and agriculture, but also turned to revolutionary ideas, became a member of the social democratic group, secretly translated writings of German socialists from the German language, disseminated illegal social-democratic literature and was caught. He was arrested (1898), imprisoned for a year in Jelgava Prison, then deported to Yelets in Russia [42].

Revolutionary ideas were known at RPI, and the students were familiar with the writings and views of Karl Marx (1818-1883). Student insurgency and taking to the study of communist ideas in the then Russian empire, including Riga, began at the end of the 19th century and continued until the beginning of the 20th century, culminating in the 1905 revolution. One of the most prominent revolutionary initiators of the institute was Stepan Shaumian (Степан Шаумян; 1878-1918), whose
Former Students of the Riga Polytechnicum and Riga Polytechnic Institute (1862-1919) Literary Workers 
year of birth in RPI documents is different - 1880. [44] In Riga, he began to study chemistry on 1 September 1900, and because of his revolutionary activities, was excluded from the studies on 2 March 1902. He continued his studies in Berlin and met a Russian revolutionary in Geneva in 1903 - this person was one of the most influential politicians of the 20th century - Vladimir Ulyanov (Latvian - Lenins; Russian - Владимир Ульянов; pseudonym - Ленин; 1870-1924). Stepan Shaumian translated into Armenian the writings of K. Marx, Lenin, and one of the founders of Marxism - Friedrich Engels (1820-1895). He was also known as a literary critic. The writings of the Armenian revolutionary and literary critic Stepan Shaumian are still kept in many libraries, including the Russian National Library in St. Petersburg. Some of them were published after his death, for example articles on literary criticism were published in Moscow in 1952 [45].

\section{Conclusions}

The diplomas of engineers were awarded to six Latvian poets and writers, but there is no news of any to have been acquired by a non-Latvian literary worker. There have been various reasons for interrupting the studies: in the second half of the 19th century and at the beginning of the 20th century, not everyone could pay a tuition fee; intentions were disrupted by the 1905 revolution, by the First World War, and by complications in personal life or health problems. Others paid more attention to their everyday jobs and did not find time for writing. For example, a civil engineer, graduate of the Department of Engineering of RPI (1909) Alfrēds Razums (1880-1929) wrote poems that were published and his interest in literature lasted throughout his life, he knew Latvian writers, including Rainis [46].

It was rarely that literary workers were devoted solely to the creation of literary writings. Most of them had paid jobs, which were often related to engineering. This is confirmed by this study, which resulted in the identification of students and graduates of the Riga Polytechnicum and Riga Polytechnic Institute, who wrote more or less well-known and successful literary works.

\section{LIST OF SOURCES AND LITERATURE}

[1] Katalog der Bibliothek der Polytechnischen Schule zu Riga. Riga: W. F. Häcker, 1895, S. 571-573, 636-637.

[2] Album Academicum des Polytechnikums zu Riga, 1862-1912. Riga: Verlag Jonck \& Poliewsky, 1912, 826 S. 
[3] Rīgas Politehnikums: 1862.-1919. g.; Album Academicum (1912.1919. g.). Rīga: Latvijas Universitātes Studentu grāmatnīca, 1938, 367 lpp.

[4] Latviešu rakstniecība biogrāfijās. Rīga: Zinātne, 2003, 741 lpp.

[5] Latviešu literatūras darbinieki. Biogrāfiska vārdnīca. Rīga: Zinātne, 1965, 375 lpp.

[6] Augstākās tehniskās izglīî̄bas vēsture Latvijā. 1. daḷa. Rīgas Politehnikums, Rīgas Politehniskais institūts: 1862-1919. Rīga: RTU, 2002, 56. lpp.

[7] Latvijas Valsts vēstures arhīvs (turpmāk - LVVA) 7175. f., 1.apr., 1907. 1., 7. lp.

[8] Treimane I. Eldgasts Haralds. Latviešu rakstniecība biogrāfijās. Rīga: Zinātne, 2003, 175. lpp.

[9] Elcbahers P. L. Tolstoja uzskati un mācība par valsti, likumiem un īpašumu. Rīga: A. Golts, 1907, 39 lpp.

[10] LVVA 3234. f., 33. apr., 69251. l., 3. lp.

[11] LVVA 1632. f., 1. apr., 541. l.

[12] Pētersons J. Alfrēdam Andersonam aizejot. Jaunākās Zinass, 1937, No. 37, 10. lpp.

[13] Rožkalne A. Uzdrīkstēties gribēt - versija par Baronu-Ērgḷu dzimtu. Literatūra un Māksla, 1992, No. 8, 14. lpp.

[14] Riharda Ērg̣̦a grāmatas «Kur atradās senā Zemgales osta?» (1938) vāks. Latvijas Nacionālās bibliotēkas krājums.

[15] Rubule I. Jānis Bergs. Latviešu rakstniecība biogrāfijās. Rīga: Zinātne, 2003, 72. lpp.

[16] Latvijas Universitāte, 1919-1929. Rīga: LU, 1929, 278. lpp.

[17] Bergs J. Česmes varons. Latviešu Avīzes, 1878, No. 25, 212.-213. lpp.

[18] Rubule I. Jānis Bergs. Latviešu rakstniecība biogrāfijās. Rīga: Zinātne, 2003, 72. lpp.

[19] LVVA 2996. f., 2. apr., 16503. l., 3. lp.

[20] Augstākās tehniskās izglīî̄bas vēsture Latvijā. 1. daḷa. Rīgas Politehnikums, Rīgas Politehniskais institūts: 1862-1919. Rīga: RTU, 2002, 203. 204., 207. lpp.

[21] LVVA 7175. f., 1. apr., 1909. l., 74. lp.

[22] Literatūra. Mācību grāmata X klasei. V izdevums. Rīga: Zvaigzne, 1980, 122.-125. lpp.

[23] Latvijas Brīvības cīnas: 1918-1920. Enciklopēdija. Rīga: Preses nams, 1999, 182. lpp.

[24] Kuri-Beri. Ierēdṇu sijāšana. Svari, 1921, No. 39, 312. lpp.

[25] Miris rakstnieks Valdmanis (Kuri-Beri). Tēvija, 1942, No. 87, 6. lpp.

[26] Štauere L. Par literatūras un teātra vēsturi Zaḷeniekos. Jelgavas Ziṇotājs, 1992, No. 65, 2. lpp.

[27] Eglītis V. Jānna Poruka nozīme latvju kultūrā un literatūrā. Ilustrēts Žurnāls, 1921, No. 11, 9. lpp.

[28] Miris rakstnieks Purinu Klāvs. Latvijas Kareivis, 1935, No. 214, 4. lpp.

[29] LVVA 7175. f., 1. apr., 1906. 1., 66. lp. 
[30] LVVA 7175. f., 1. apr., 1909. l., 135. lp.

[31] Dambergs V. Kārlis Jēkabsons. Ritums, 1923, No. 8, 595. lpp.; No. 9, 674. lpp.; No. 10, 758. lpp.

[32] Jegermanis G. Kārlis Jēkabsons. Latviešu rakstniecība biogrāfijās. Rīga: Zinātne, 2003, 261. lpp.

[33] Vīksna A. Pacients nošauj ārstu. Pieejams: http://medhistrigensia.mvm. lv/2015/07/pacients-nosauj-arstu/ [skatīts: 20.11. 2017].

[34] LVVA 7175. f., 1. apr., 1907. l., 104. lp.

[35] LVVA 7175. f., 1. apr., 1910. l., 201. lp.

[36] Admirālis Teodors Spāde [sast. Mārtinšs Bisters un Juris Ciganovs]. Rīga: Valters un Rapa, 2002, 135. lpp.

[37] Jermaks R. Sāpju cel̦š: oratorija. Rīga, 1999.

[38] Admirālis Teodors Spāde [sast. Mārtinš̌ Bisters un Juris Ciganovs]. Rīga: Valters un Rapa, 2002, 5. lpp.

[39] Gottzmann C., Hörner P. Lexikon der deutschsprachigen Literatur des Baltikums und St. Petersburgs. Band 2. Berlin, New York: W. de Gruyter, 2007, S. 659, 870.

[40] LVVA 7175. f., 1. apr., 1904. 1., 129. lp.

[41] Lavrenova J. Prishvin Mihail Mihailovich (1873-1954).

Pieejams: http://www.foxdesign.ru/aphorism/biography/prishvin.html [skatīts: 19. 11. 2017].

[42] LVVA 7175. f., 1. apr., 1906. 1.,155.lp.

[44] A. U. Alfreda Razuma pieminnai. Domas, 1929, No. 8, 239. lpp.

[45] Shaumjan S. G. Literaturno-kriticheskiji statji (Podgot. teksta i orimech. A. Voskerchjana). Moskva: Goslitizdat, 1952, 92 s.

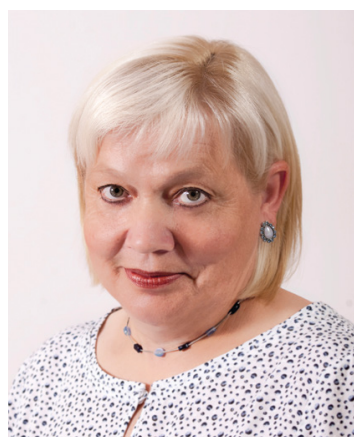

ALĪDA ZIGMUNDE, Dr. paed., has been a Specialist at the Museum of Riga Technical University since 1989. From 2007 to 2015, she was a Senior Researcher. She is currently a Professor at the Institute for Humanities and Head of the Department for Historic Research and Scientific Publications of the RTU Research Centre for Engineering History. Her main academic interests include the history of pedagogy in Europe, the history of the institutions of education and of private schools, and the history of pedagogy of universities, history of engineering sciences and universities.

Address: 1 Kronvalda Boulevard, Riga, LV-1010, Latvia

Phone: +37129869642

E-mail: alida.zigmunde@rtu.lv 


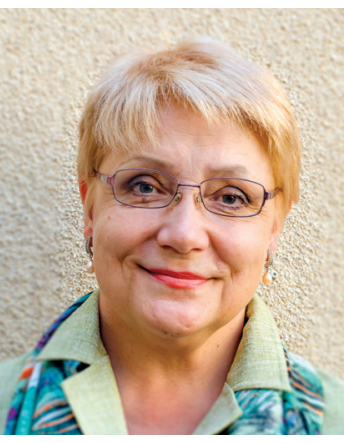

ĒRIKA LANKA, Mg. paed., Mg. phil., graduated from

Former Students University of Latvia. From 1984, she is a lecturer at the Faculty of Education at University of Latvia, since 2008 she has been Director of one of the Programs at the Centre of Adult Pedagogical Education of the Faculty of Education, Psychology and Art. She has participated as an expert in a number of Latvian and foreign research projects, at the same time working as a school teacher. Her main academic interests include the philosophy of education, ethics, axiology, values and codex of teacher, history of pedagogy in Latvia and in Europe. She is a co-author of two monographies and the author of more than 30 publications.

Address: 76 Jūrmalas gatve, Riga, LV-1083, Latvia

Phone: +37129264829

E-mail: erika.lanka@lu.lv,erikalanka@inbox.lv

ELITA STIKUTE, Dr. paed., is an Associate Professor of the Teachers Training Department of the Faculty of Education, Psychology and Art of University of Latvia. Her scientific interests are history of pedagogy, didactics and history of Latvian literature, critical thinking approach in learning process.

Address: 76 Jürmalas gatve, Riga, LV-1083, Latvia

Phone: +37126414041

E- mail: elita.stikute@lu.lv

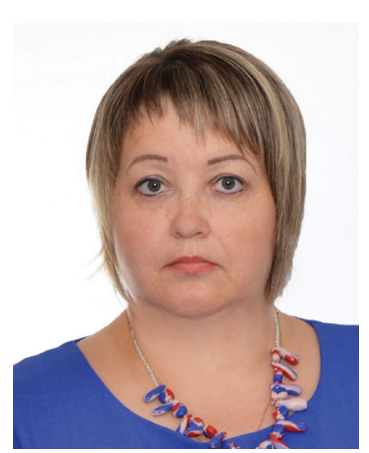

ZANDA ŠLEGELMILHA, Mg. paed., is a teacher at Kuldiga Technology and Tourism Technical School. Her scientific interests are literature, Latvian language, problems of education.

Address: 31 Liepājas Street, Kuldīga, LV-3301, Latvia

E-mail: slegelmilha@inbox.lv

Alīda Zigmunde, Ërika Lanka, Elita Stikute, Zanda Šlegelmilha

\section{Rìgas Politehnikuma un Rīgas Politehniskā institūta (1862-1919) studenti - literāti}

Rakstā apkopots Rīgas Politehnikuma (RP) un Rīgas Politehniskā institūta (RPI) kādreizējo studentu - dramaturgu, dzejnieku un rakstnieku - veikums literatūrā, kā arī raksturota viṇu darbība. Augstskolā studējuši vairāki latviešu un cittautu literāti. Inženiera diplomu, studējot Inženieru, Komercijas un 
Lauksaimniecības nodaḷās, ieguvuši vien seši no viṇiem - Alfrēds Andersons, Jānis Bergs, Rihards Ērglis, Ernests Eferts, Jānis Miḳelsons un Arvīds Valdmanis. Augstskolā studējuši arī latviešu rakstnieks Jānis Poruks un krievu rakstnieks Mihails Prišvins, kuri, tāpat kā daži citi, par inženieriem nekḷuva, bet ir pazīstami, pateicoties veikumam daillliteratūrā. Dzejoḷus rakstījis arī absolvents admirālis Teodors Spāde. Raksts tapis, izmantojot Rīgas Tehniskās universitātes (RTU) Inženierzinātṇu vēstures pētniecības centra krājumu, arhīvu un bibliotēku materiālus. Tajā pirmo reizi apkopotas ziṇas par Rīgas Politehnikuma / Rĩgas Politehniskā institūta studentiem - literātiem un sniegts īss viṇu raksturojums.

Atslēgas vārdi: Rīgas Politehnikums, Rīgas Politehniskais institūts, literāti ar inženiera izglītību.

Алида Зигмунде, Эрика Ланка, Элита Стикуте, Занда Шлегелмилха

\section{Студенты-литераторы Рижского политехникума и Рижского политехнического института (1862-1919)}

В статье обобщен вклад бывших студентов Рижского политехникума (РП) и Рижского политехнического института (РПИ) - драматургов, поэтов и писателей - в литературу, а также дается характеристика их деятельности. В вузе училось несколько латышских литераторов и литераторов других национальностей. Диплом инженера, обучаясь на отделениях Инженеров, Коммерции и Сельского хозяйства, получили шестеро из них - Алфред Андерсонс, Янис Бергс, Рихард Эрглис, Янис Микелсонс и Арвид Валдманис. В вузе учились также латышский писатель Янис Порукс и русский писатель Михаил Пришвин, которые также, как некоторые другие, инженерами не стали, но известны, благодаря своему вкладу в литературу. Стихи писал также и выпускник адмирал Теодор Спаде. При написании статьи использованы материалы Центра по исследованию истории инженерно-технических наук Рижского Технического университета, архивов и библиотек. Впервые была обобщена информация о студентах литераторах Рижского политехникума / Рижского политехнического института и дана краткая их характеристика.

Ключевые слова: Рижский политехникум, Рижский политехнический институт, литераторы с инженерным образованием. 